\title{
Failure to launch: aberrant cumulus gene expression during oocyte in vitro maturation
}

\author{
Hannah M Brown ${ }^{1,2}$, Kylie R Dunning ${ }^{1}$, Melanie Sutton-McDowall ${ }^{1,2}$, Robert B Gilchrist ${ }^{3}$, \\ Jeremy G Thompson ${ }^{1,2}$ and Darryl L Russell ${ }^{1}$ \\ ${ }^{1}$ The Robinson Research Institute, School of Medicine, ${ }^{2}$ Australian Research Council Centre of Excellence for \\ Nanoscale BioPhotonics, The University of Adelaide, Adelaide, South Australia, Australia, and ${ }^{3}$ Discipline of \\ Obstetrics and Gynaecology, School of Women's and Children's Health, University of New South Wales, \\ Sydney, New South Wales, Australia
}

Correspondence should be addressed to D L Russell; Email: darryl.russell@adelaide.edu.au

\begin{abstract}
In vitro maturation (IVM) offers significant benefits for human infertility treatment and animal breeding, but this potential is yet to be fully realised due to reduced oocyte developmental competence in comparison with in vivo matured oocytes. Cumulus cells occupy an essential position in determining oocyte developmental competence. Here we have examined the areas of deficient gene expression, as determined within microarrays primarily from cumulus cells of mouse COCs, but also other species, between in vivo matured and in vitro matured oocytes. By retrospectively analysing the literature, directed by focussing on downregulated genes, we provide an insight as to why the in vitro cumulus cells fail to support full oocyte potential and dissect molecular pathways that have important roles in oocyte competence. We conclude that the roles of epidermal growth factor signalling, the expanded extracellular matrix, cumulus cell metabolism and the immune system are critical deficiencies in cumulus cells of IVM COCs.

Reproduction (2017) 153 R109-R120
\end{abstract}

\section{Introduction}

In vitro maturation (IVM) of oocytes is a potentially valuable technology for both clinical infertility treatment and assisted reproductive technologies in animals (Gilchrist \& Thompson 2007). IVM has been and remains a valuable research tool in understanding factors that irrefutably influence oocyte developmental competence. Indeed, the great majority of studies investigating the regulation of oocyte competence are performed in vitro. Through such studies, it is clear that the cumulus has substantial influence on oocyte biology, including (but certainly not exclusively): the supply of small molecular weight molecules involved in the regulation of meiotic maturation and metabolism of the oocyte; the acquisition of cytoplasmic signalling mechanisms enabling further development by the oocyte; the induction of sperm capacitation enabling penetration of the oocyte. This is clearly observed when developmental competence is compared between cumulus-enclosed and denuded oocytes during IVM (e.g. Younis \& Brackett 1991, Hazeleger et al. 1995, Zhang et al. 1995, Luciano et al. 2005), where denudation results in a significant drop in developmental capability. Furthermore, this is not attributed to simply poor fertilisation, as parthenogenic activation rates differ in oocytes denuded of cumulus cells prior to maturation compared with intact COCs in the presence of FSH (Chian et al. 1995).

Despite several decades of research, IVM-derived oocytes of most species have a perceptively poorer developmental outcome than those derived following in vivo maturation, even despite recent advances suggesting the gap is closing (Walls et al. 2012, 2015). Bi-directional communication between the cumulus vestment and oocyte is critical for oocyte competence and has been the subject of many previous reviews (Gilula et al. 1978, Gilchrist et al. 2008, Kidder \& Vanderhyden 2010). However, this communication is under stress during in vitro maturation relative to in vivo maturation. We proposed that, compared to in vivo derived COCs, the cumulus cells of an in vitro matured COC would exhibit significantly different gene expression patterns which may indicate aspects of cumulus cell function that are deficient, therefore leading to reduced oocyte quality. Our analysis was primarily informed by the differential expression between in vivo and in vitro mouse cumulus cell genes published not only by Kind et al. (2013), but also by Tesfaye et al. (2009) (bovine CC) and Ouandaogo et al. (2012) (human CC). We acknowledge that variations in species and in methodology used for the generation 

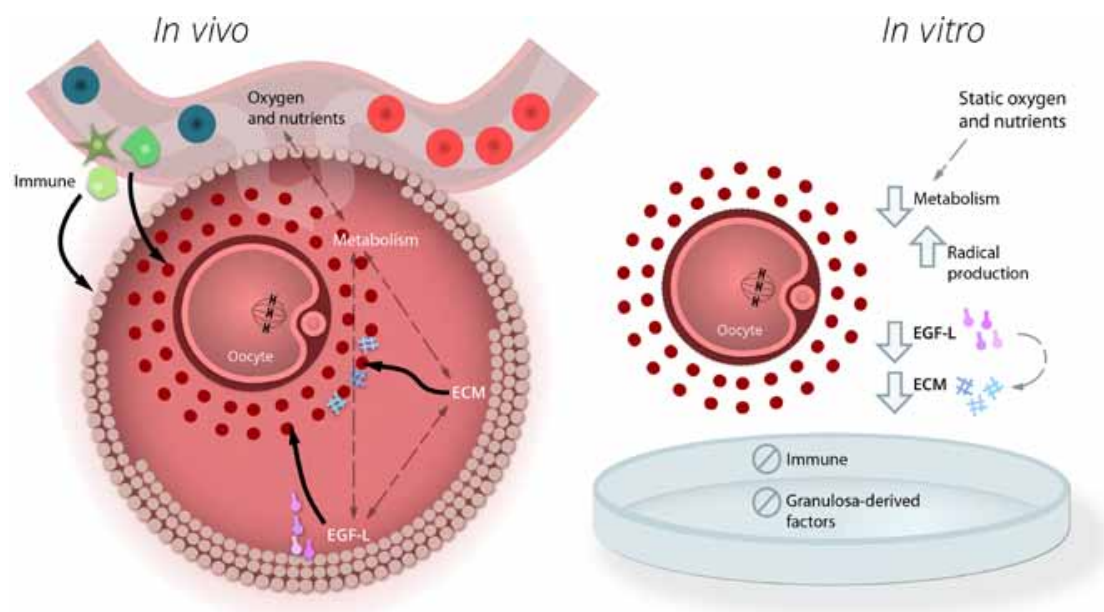

Figure 1 During IVM, the dynamic niche environment controlled by the ovarian follicle in vivo is lost. Global analysis of gene expression differences between in vivo and IVM-derived COC demonstrate deficiencies in a range of cellular pathways. Metabolites and endocrine hormones provided through the maternal system are dysregulated, and paracrine factors from follicular somatic cells (granulosa and or theca) are diminished, dysregulating the sensitive progression to oocyte competence. of both in vivo and in vitro matured COCs may cause differences in the cumulus cell transcriptome, and that differences in microarray platforms will contribute a significant source of variation in results. Our intent is not to discuss closely the results of these microarrays, but use them as a guide to direct us to the major networks in cumulus cells leading to reduced developmental competence of oocytes in vitro (Fig. 1). In doing so, we have focussed on major distinct physiological processes with evident dysregulation because of IVM, and expand to what is known about their role in oocyte maturation.

\section{Epidermal growth factor receptor signalling}

Of the seven recognised cognate epidermal growth factorlike ligands (EGF-L), three are known to be expressed in granulosa cells and COCs; amphiregulin (AREG), epiregulin (EREG) and betacellulin (BTC), and all were significantly reduced in IVM COCs compared to in vivo (Kind et al. 2013). Deficient expression of EGF-L factors in IVM has been confirmed in a number of subsequent studies (Richani et al. 2013, 2014b). Additionally, Versican is another factor with demonstrated EGFlike activity in COC (Dunning et al. 2015), which was also reduced in IVM compared to in vivo COCs as has been previously demonstrated (Dunning et al. 2007). The EGF signalling pathway is fundamental for oocyte maturation and this has been established over several decades (Downs et al. 1988). More recently, the specific importance of AREG, EREG and BTC was demonstrated (Park et al. 2004). The EGF-L factors and Versican are rapidly (within $1 \mathrm{~h}$ ) induced in granulosa cells responding to the LH-surge and transmit the ovulatory signal to cumulus cells which are not directly LH responsive (Eppig et al. 1997). This important intermediary paracrine role played by granulosa cell derived EGF-L factors in activation of oocyte maturation has been confirmed using whole follicle culture (Ashkenazi et al. 2005) and genetic dissection (Hsieh et al. 2011). Likewise, a role for granulosa-derived Versican in expansion of the COC matrix has been demonstrated (Dunning et al. 2012, 2015). However it is also clear that once maturation of the COC is activated by granulosa derived factors, these same factors are subsequently induced in cumulus cells and hence likely to maintain an autocrine activation of the EGF signalling pathway throughout oocyte maturation, ovulation and fertilisation (Shimada et al. 2006b). Expression of these factors in cumulus cells has been shown to associate with oocyte developmental potential (Gebhardt et al. 2011, Huang et al. 2015), and their deficient expression in IVM systems is therefore likely to be a key contributor to lower quality outcomes. Recently it has come to light that the EGF receptor activation in cumulus cells stimulates PI3K/ AKT signalling in the oocyte which controls protein translation and developmental competence (Chen et al. 2013, Franciosi et al. 2016). The increase in protein translation promotes release of factors such as IL7 from oocytes which act back on cumulus cells (Cakmak et al. 2016). Exactly how the cumulus cell response is transferred to the oocyte remains unknown, but the importance of EGF-L induction in granulosa cells and hence the importance of replicating this pathway in vitro is clear.

These findings have initiated a trend towards including EGF or EGF-L factors in stimulated IVM systems. A number of studies have undertaken comparison of IVM outcomes using treatment with FSH vs EGF or each of the EGF-L factors as COC maturation stimuli. While more evaluation of dose responses are required to properly compare the activity of each factor in IVM COCs, the consensus findings indicated that when compared at $50 \mathrm{ng} / \mathrm{mL}$, recombinant EREG had the greatest beneficial effects on mouse COC glycolysis (Sugimura et al. 2014), oocyte mitochondrial activity (Richani et al. 2014a) and embryo developmental potential (Richani et al. 2014b), although why EREG was better at promoting these processes is undetermined. Other studies have suggested AREG may play the most important role in oocyte maturation. A non-redundant 
contribution of AREG to mouse oocyte maturation in vivo was illustrated by null mutation of AREG causing delayed meiotic progression (Hsieh et al. 2007) and a significant $40-50 \%$ reduction in the proportion of oocytes that could achieve fertilisation (Chen et al. 2013). Likewise in human and rhesus monkeys AREG protein was found to be more abundant (median $30 \mathrm{ng} / \mathrm{mL}, 36 \mathrm{~h}$ after hCG) than other EGF-L factors in the follicular fluid of mature follicles (Zamah et al. 2010, Peluffo et al. 2012). The concentration of AREG in follicular fluid was correlated with oocyte developmental potential (Zamah et al. 2010), however, potential juxtacrine signalling within COC by AREG or the other EGF-L is not considered in this approach investigating the free ligand in antral fluid which may indeed be less biologically relevant. A dose-response analysis in porcine COCs showed that AREG at $100 \mathrm{ng} /$ $\mathrm{mL}$ significantly increased oocyte maturation to MII (Sugimura et al. 2015). Another recent study found AREG mRNA induction in human granulosa cells or in COC correlated with ICSI success parameters including numbers of oocytes retrieved, meiotic progression, fertilisation and embryo quality (Huang et al. 2015). These studies together suggest that AREG may be most important and should be tested in primate IVM.

The normal in vivo induction of EGF-L factors involves sequential increases in the three factors with overlapping but different kinetics. This may promote a specific temporal pattern of signalling in the COC which is difficult to replicate in IVM and the physiological importance of this sequence for full oocyte developmental potential is unknown. Supplementation of IVM cultures with EGF promotes EGF-L mRNA expression to levels quantitatively similar to in vivo COCs, yet levels of EGF receptor phosphorylation at Tyrosine $\mathrm{Tyr}^{1068}$ remain generally lower than in vivo and differ in temporal kinetics (Richani et al. 2013). Variable responses to the different EGF-L ligands are mediated in part through interaction with distinct receptors or receptor complexes. All seven cognate EGF related factors can bind and activate EGF-receptor (EGFR or ERBB1), but some also bind other members of the ERBB receptor family, such as BTC which can activate all the ERBB members (Dahlhoff et al. 2014). Likewise Neuregulin 1 (NRG1) is an EGF-like factor induced in granulosa cells during oocyte maturation in vivo (Noma et al. 2011), but which binds only ERBB2 and ERBB3, not ERBB1. The rapid induction of $\mathrm{Nrg} 1$ in granulosa cells may initially suppress oocyte maturation and has thus been proposed to be an important granulosa-derived factor helping to synchronise maturational events in vivo (Kawashima et al. 2014). Because Nrg1 is not a cumulus gene product it is not found among differentially expressed genes in IVM COC; however, it is deficient due to the absence of granulosa cells and may explain the abnormally rapid meiotic maturation of IVM oocytes (Kawashima et al. 2014).
In addition to the different ligand-receptor affinities, variable phosphorylation of intracellular Tyr residues on the EGF receptors is activated by the different ligands (Wilson et al. 2012), with important distinctions in internalisation and recycling of the receptors and affecting the signalling duration. Amphiregulin promotes receptor recycling to epithelial cell membranes, while EGF and BTC traffic the receptor to lysosomes for degradation (Roepstorff et al. 2009), which will truncate signal duration and blunt the cell's capacity to respond to other EGF-L whether exogenously added or endogenously produced. This outcome is consistent with what has been described for EGFR Tyr ${ }^{1068}$ phosphorylation in IVM COC, which show a sharp rapid induction, but premature downregulation (Richani et al. 2013). Finally, some of the EGF-L ligand's signalling is modulated by heparan sulphate proteoglycans on the cell surface or the local ECM environment. Amphiregulin action is dependent on heparan sulphate (Mahtouk et al. 2006), and the expression of many HSPG is altered under IVM conditions (Watson et al. 2012). Together all these differences weave a tapestry of complex signal transduction consequences contingent on the mix and timing of ligands and receptors present. The specific combination and timing of EGFR signalling in COC maturation is clearly important, but has yet to be investigated in detail. Likewise, the involvement of HSPG in cumulus cell signalling is just emerging (Watson et al. 2012). The collective deficiency in expression of AREG, EREG and BTC and other signalling molecules is clearly suboptimal and likely to result in lower autocrine activation of the EGF pathway in IVM COCs.

An alternative IVM technology that uses a prematuration treatment to elevate cAMP before stimulating $\mathrm{COC}$ with $\mathrm{FSH}$ and/or EGF, improved oocyte competence in cows (Albuz et al. 2010) and mice (Zeng et al. 2014) and enhances EGF-L peptide expression (Richani et al. 2013, 2014b). However, ERK $1 / 2$ phosphorylation, which is a downstream consequence of EGF-L activity, was not different (Richani et al. 2013, 2014b). The results are suggestive that increased EGF-L production caused by elevated CAMP activated signalling in the prematuration phase was responsible for higher oocyte developmental competence (Richani et al. 2014b).

Versican is profoundly deficient in IVM COC in mouse (Dunning et al. 2007) and its expression in human cumulus cells has been repeatedly found to be associated with successful ART outcomes (Gebhardt et al. 2011, Wathlet et al. 2011, Ekart et al. 2013, Hammond et al. 2015). The capacity of Versican to activate EGFR in cumulus cells and promote COC maturation was also recently discovered (Dunning et al. 2015). While the ability of Versican to bind and activate EGFR is known (Du et al. 2010), its specific downstream signal transduction mechanism is unknown. Importantly, the temporal kinetics of gene 
induction mediated by Versican in COC was more similar to the in vivo pattern than that achieved by EGF treatment (Dunning et al. 2015). Of particular interest, induction of Ereg and Ptgs 2 by Versican was more sustained than with EGF (Dunning et al. 2015) mimicking more closely the expression profile observed in vivo (Shimada et al. 2006b). Based on the sustained signalling capacity of Versican, we believe it to be an important component of the periovulatory signalling cascade and that its absence during IVM impacts on oocyte quality. It will be of interest to determine whether Versican has similar signalling capacity in human cumulus cells and whether this is a key missing aspect of EGF pathway activation important for high oocyte developmental potential after IVM.

Together these findings on the role of EGF-L factors in activation of $\mathrm{COC}$ maturation and the evident importance of local EGF-L production in COC for acquisition of full oocyte developmental potential suggest that the lower EGF-L production in IVM is expected to be one aspect that has a negative influence on developmental potential. The most plausible explanation at present is that a vicious cycle arises whereby key mural granulosa cell derived contributors to COC maturation are absent in vitro resulting in deficient expression of critical factors (e.g. EGFL, Versican, or HSPG), which further diminish the activation of key signalling pathways in the IVM COC.

\section{Extracellular matrix}

The in vivo action of the ovulatory LH-surge also stimulates production of an extensive extracellular matrix in the COC. Again this requires granulosa cells which produce a variety of factors that impinge on cumulus cells resulting in the induction of ECM gene expression while some granulosa cell secreted proteins (e.g. versican and Adamts1) are directly incorporated into the COC matrix (Russell \& Salustri 2006, Russell \& Robker 2007). The resultant phenomenon, known as cumulus expansion, occurs concomitantly with oocyte meiotic maturation and is required for ovulation (Russell \& Robker 2007). Cumulus expansion has been described in nearly all mammalian species investigated to date, yet historically its role was thought to have been restricted to its functionality during oocyte pick-up by the infundibulum (Odor \& Blandau 1973, Lam et al. 2000) and during fertilisation in the oviduct (Salustri et al. 2004). In recent years studies have shown that formation of a compositionally complete and functional cumulus matrix is associated with oocyte quality (McKenzie et al. 2004, Cillo et al. 2007, Yung et al. 2010, Gebhardt et al. 2011, Wathlet et al. 2011, Ekart et al. 2013), ovulation rate (Varani et al. 2002, Fulop et al. 2003, Ochsner et al. 2003, Mittaz et al. 2004, Brown et al. 2006), cumulus cell signalling (Dunning et al. 2015), adhesive and invasive capacity of the COC (Akison et al. 2012) and molecular filtration (Dunning et al. 2012). Importantly, the cumulus matrix formed during in vitro maturation is compositionally and functionally altered and may account for the poorer quality of oocytes produced using this technology (Dunning et al. 2007, 2012, Kind et al. 2013).

In vivo, the EGF-L peptides secreted by granulosa cells, as described above, act on cumulus cells to induce genes such as prostaglandin endoperoxide synthase 2 (Ptgs2) involved in cumulus matrix gene expression and hyaluronan synthase (Has2), tumour necrosis alpha induced protein 6 (Tnfaip6), pentraxin 3 (Ptx3). These matrix components interact, along with versican from the granulosa cells and inter-alpha trypsin inhibitor heavy chain from circulation, to assemble the COC matrix (Russell \& Salustri 2006). Another granulosa product, Adamts 1 is progesterone-dependently induced in granulosa cells following the LH-surge and found in abundance in the expanded COC (Russell et al. 2003a,b). In vitro it is clear that expression of cumulus matrix genes is truncated or temporally altered (Jones et al. 2008, Wells \& Patrizio 2008, Tesfaye et al. 2009, Kind et al. 2013, Dunning et al. 2015) and this is associated with the poor oocyte developmental competence. Cumulus expansion also requires calpain-mediated migration of cumulus cells along the newly synthesised cumulus matrix (Kawashima et al. 2012). Whether cumulus cell motility during IVM is altered and functionally impacts oocyte quality is yet to be determined.

We have shown that following IVM the expanded mouse COC is completely void of the cumulus matrix proteins ADAMTS1 and Versican despite their abundance in the in vivo matured COC (Dunning et al. 2007). The absence of these proteins and the reduced abundance of other cumulus matrix components results in a compositionally deficient and functionally altered matrix. We have shown that the in vivo matured matrix is able to restrict diffusion of metabolites to the oocyte such as glucose and sequester locally produced signalling molecules including prostaglandin E2 (Dunning et al. 2012). This molecular filtration property of the cumulus matrix is however deficient following IVM (Dunning et al. 2012). The ability of the cumulus matrix to regulate metabolite supply while retaining cumulus cell synthesised signalling factors is likely to affect oocyte quality. It is logical that the loss of the ECM capacity to retain and concentrate locally produced factors contributes to poor IVM quality since the gene products involved in prostaglandin synthesis, oocyte secreted growth factors and glucose metabolism are associated with oocyte quality, and supplementation of IVM media with the products of these pathways improves oocyte quality (Hussein et al. 2005). Thus, the reduced oocyte quality following IVM may be due to dysregulated control of oocyte exposure to metabolites and signalling molecules. Whether similar deficiencies in cumulus matrix filtration occurs following IVM of human COCs 
has not been determined, nor whether repletion of the mouse cumulus matrix through exogenous addition of proteins such as Versican restores this function.

Extracellular matrix proteins can also function as signalling molecules. As described above, recombinant Versican induces cumulus-specific gene expression during IVM (Dunning et al. 2015). Other ECM proteins such as heparan sulphate proteoglycans can also either directly transduce an intracellular signal (e.g. Syndecans) or modulate signalling by EGF, FGF or TGFb family ligands.

That the cumulus matrix is important for oocyte quality is clearly supported by several studies associating human cumulus ECM gene expression with oocyte developmental potential. The expression of Versican (VCAN) has been positively correlated with oocyte developmental potential in four independent studies including a positive association with live birth (Gebhardt et al. 2011, Wathlet et al. 2011, Ekart et al. 2013, Hammond et al. 2015). Similar positive associations have been shown for Ptgs2, Adamts 1 and Has2 (McKenzie et al. 2004, Cillo et al. 2007, Yung et al. 2010, Xu et al. 2015). These retrospective results have yet to be confirmed using randomised controlled trials; however, the independent findings at different sites of consistent associations between cumulus matrix gene expression and oocyte developmental outcomes provide strong evidence that formation of an appropriate cumulus matrix is essential for human oocyte quality. Whether human cumulus expression of matrix genes is similarly reduced during IVM as occurring in the rodent is yet to be determined and should be investigated.

\section{Metabolism}

The importance of the cumulus cell supply of nutrients and substrates to the oocyte to achieve developmental competence has been increasingly acknowledged over the last two decades (Dumesic et al. 2015). Metabolism of cumulus cells is an important contributor to the bi-directional communication between the oocyte and cumulus vestment (Eppig 1991, Albertini et al. 2001, Matzuk et al. 2002). The environment to which a COC is exposed to during maturation, both in vivo and in vitro, largely impacts its metabolism and developmental competence (Krisher 2013, Dumesic et al. 2015). For example, maternal hyperglycaemia and hyperlipidaemia compromise COC health, embryo development and pregnancy outcomes (Chang et al. 2005, Leroy et al. 2008, Robker 2008, Purcell \& Moley 2011, Van Hoeck et al. 2011). It is well established that the oocyte predominantly utilises oxidative phosphorylation, whereas the cumulus vestment has a high rate of glycolytic activity (Thompson et al. 2007). The primary substrate of cumulus cells is glucose and is metabolised via numerous pathways to provide energy, substrates for ECM, nucleic acid synthesis and stress/fuel sensing (reviewed by Sutton-McDowall et al. 2010). Therefore the discovery that several genes in the glucose metabolic pathway have reduced expression during IVM suggests glycolytic deficiency is likely to negatively impact on oocyte developmental potential. These included S/c2a 1 (facilitated glucose transporter 1), lactate dehydrogenase $(L d h d)$, enolase (Eno2) and hexokinase (Hk2) expression and indicate a reduced glucose uptake and metabolism (Kind et al. 2013). Cumulus cell glucose metabolism is regulated by oocyte-secreted factors, which influence the expression of such genes (Sugiura \& Eppig 2005, Sugiura et al. 2005, 2007), and the array results are in line with a reduction in OSF expression during IVM (Mester et al. 2015). Furthermore, glucose (and glutamine)-dependent hyaluronic acid matrix production is most likely inhibited by reductions in glutamine-fructose-6-phosphate transaminase (Gfpt1) and hyaluronic acid synthase 2 (Has2) expression within in vitro matured cumulus cells (Caixeta et al. 2013). This is despite many IVM systems utilising follicle stimulating hormone, a potent stimulator of cumulus glucose metabolism and nuclear maturation within COCs (Downs et al. 1996, Sutton-McDowall et al. 2004).

Fatty acid metabolism via beta-oxidation is a potent source ofcellularenergy. Theimportanceofbeta-oxidation during COC maturation is becoming increasingly recognised. In vivo, the $\mathrm{LH}$-surge results in a significant increase in beta-oxidation-related genes in COCs and functional assays demonstrate a significant increase in beta-oxidation during in vitro maturation (Dunning et al. 2010). Further, pharmacological inhibition of betaoxidation impairs oocyte developmental competence, while promotion with L-carnitine during IVM improves subsequent embryo development in several species (Dunning et al. 2010, 2014, Dunning \& Robker 2012). Thus it appears that supply of a fatty acid milieu and necessary co-factors such as L-carnitine that replicates the in vivo environment is likely to result in improved oocyte maturation conditions in vitro.

An emerging interest is the negative impact on oocyte competence of 2-carbon glucose metabolic products, such as glyoxal and methylgloxal (reactive carbonyl species, RCS) (Tatone et al. 2010, 2011). RCS are derived from glycolysis and the polyol pathway, plus other sources, and are damaging in that they promote lipid peroxidation (Tatone et al. 2010, 2011). Reduction in 2-carbon derivative detoxification enzymes, such as carbonyl reductase (NADPH) 3 (Cbr3) within in vitro matured cumulus cells is evidence that 2-carbon toxicity may occur (Tatone et al. 2010, 2011), and this area requires more attention.

We have recently reported that haemoglobin A1 and $\mathrm{B}$ expression (Hba-a1 and $\mathrm{Hb}$, respectively) greatly differed in mouse cumulus cells derived from in vivo or in vitro maturation, where they were at nearly undetectable levels following in vitro maturation (Kind et al. 2013). Indeed, Hba-a1 was the most 
differentially expressed gene from the microarray analysis. This was validated by a substantial loss of HBA protein following in vitro maturation (Kind et al. 2013, Brown et al. 2015). Significantly, this difference in gene expression is supported for both $H B A 1$ and $H B B$ within in vivo vs in vitro matured human cumulus cells (Ouandaogo et al. 2012) (Supplementary Table within publication) and for $H B B$ in bovine cumulus cells (Tesfaye et al. 2009). Our analysis of the temporal gene expression pattern following the ovulatory luteinising hormone (LH) surge demonstrated these two genes were hormonally regulated, with the peak expression level occurring 12-h post hCG. Haptoglobin, required for iron-recycling from haem degradation, also followed this pattern of expression (Brown et al. 2015). Other gene products involved in haem synthesis were also detected, but not hormonally regulated.

The function of haemoglobin within the follicular cells of antral follicles has yet to be determined, but as its presence is hormonally regulated and extends to the oocyte itself (Brown et al. 2015), we have proposed it plays a role during the ovulatory period (Thompson et al. 2015), perhaps involving $\mathrm{O}_{2}$ and/or $\mathrm{NO}$ binding and sequestering. A further potential role is as an antioxidant (Thompson et al. 2015). Work is continuing to investigate these options by developing purposefully designed molecular tools to measure haemoglobin-gas interactions.

In addition to haemoglobins and haptoglobin, there are several well-characterised $\mathrm{O}_{2}$-sensitive genes that are upregulated within mouse in vivo matured cumulus cells relative to in vitro matured cumulus cells. These include: endothelin 2 ( $E d n 2)$; enolase 2 (Eno2); BCL2/adenovirus E1B interacting protein 1, NIP3 (Bnip3); solute carrier family 2 member 1 (S/c2a 1$)$; lactate dehydrogenase D (Ldhd); hexokinase 2 (Hk2); N-myc downstream regulated gene 1 ( Ndrg 1), NADH dehydrogenase (ubiquinone) 1 alpha subcomplex, 4-like 2 (Ndufa4/2) and vascular endothelial growth factor A (Vegfa) (Kind et al. 2013). Such a pattern of expression points to involvement of the hypoxia inducible factor (HIF) family of transcription factors in regulating cumulus cell function, especially in low levels of dissolved $\mathrm{O}_{2}$. HIF transcription factors are now understood to at least partly mediate gonadotrophin signalling in the ovarian follicle, especially granulosa cells signalling following the luteinising hormone surge (reviewed by Thompson et al. 2015). We have experimentally demonstrated that maturation of COCs in vitro under low $\mathrm{O}_{2}$ concentrations (2\% and 5\%) involves HIF-induced transcription activity within cumulus cells. Similar upregulation of $\mathrm{O}_{2}$-sensitive genes in bovine cumulus cells is observed following maturation under $5 \% \mathrm{O}_{2}$ relative to $20 \% \mathrm{O}_{2}$ (Bermejo-Alvarez et al. 2010). Does this suggest that in vitro maturation should be performed at low $\mathrm{pO}_{2}$ (specifically $5 \%$ )? Several publications support the concept that IVM under low $\mathrm{pO}_{2}$ conditions improves oocyte maturation, including human IVM (Hashimoto et al. 2000a, Iwamoto et al. 2005, Preis et al. 2007, Walls et al. 2015). Nevertheless, long-term follow-up studies are virtually absent, with the study of Banwell et al. (2007) being the exception. This study reported improved embryo development from low $\mathrm{O}_{2}$ IVM, but post-transfer outcomes were impacted dependent on $\mathrm{O}_{2}$ concentration with, surprisingly, 5\% $\mathrm{O}_{2}$ IVM derived foetuses with poorer developmental indices relative to $2 \%$ or $20 \%$. A feature of this latter study is that several $\mathrm{O}_{2}$ concentrations for IVM were assessed. In contrast, virtually all other studies investigate $5 \%$ vs 'air' $\mathrm{O}_{2}$ concentrations. The historical origin for 5\% $\mathrm{O}_{2}$ gas applied to gamete and embryo culture derives from work performed several decades ago showing it was optimal for mouse embryo culture (Quinn \& Harlow 1978). Whether it has relevance or not to IVM in any species, in particular human IVM, has not been properly assessed. Furthermore, if haemoglobin does have a role to sequester gases, does this impact the optimal IVM gas composition when haemoglobin is present during IVM conditions, as suggested by Brown et al. (2015)? An often touted reason for the use of $5 \% \mathrm{O}_{2}$ atmosphere during IVM is the reduction in reactive oxygen species (ROS) production, therefore safeguarding the integrity of chromatin conformation and prevention of lipid and protein oxidation within the maturing oocyte from ROS-induced damage (Hashimoto et al. 2000a,b, Salavati et al. 2012). Therefore it would appear that a lower than atmospheric $\mathrm{O}_{2}$ concentration is preferable, but which concentration is optimal will depend on numerous factors, such as species, composition of medium and the incubation environment as a whole.

Reduced glutathione (GSH) is an essential peptide determining oocyte competence (Sutovsky \& Schatten 1997, Furnus et al. 1998, de Matos \& Furnus 2000, Bing et al. 2002). Additionally glutathione peroxidase- 1 (GPX1) expression in cumulus cells was also recently shown to be associated with human oocyte competence (Ceko et al. 2015). Metabolism in the cumulus cells is directly linked to GSH levels in the oocyte (Xie et al. 2016). Increasing intra-oocyte GSH levels by the addition of component amino acids, especially cysteine, into in vitro maturation medium formulations is a common strategy to improve embryo production (de Matos \& Furnus 2000). Several studies demonstrate cumulus cells are a source of reduced GSH for the oocyte, especially while gap junctions between oocyte and cumulus cells are patent (Curnow et al. 2008, 2010, Furnus et al. 2008). Glutathione-S-transferase (Gsta) is a key enzyme in the process of reducing oxidised glutathione, thus regenerating $\mathrm{GSH}$ levels. It is therefore pertinent that microarrays (e.g. Kind et al. 2013, Salhab et al. 2013) revealed a reduced level of Gsta transcription within the cumulus of in vitro matured COCs.

With the exception of cholesterol metabolism and steroid synthesis, little is known of lipid synthesis and metabolism within cumulus cells. Much of the focus has 
been directed towards the oocyte itself (Thompson et al. 2014). Recent insights reveal that compared to lipid within the oocyte, cumulus cell lipid composition is most vulnerable to exogenous factors such as oxidants, suggesting the cumulus lipid content is 'protecting' oocyte cytoplasmic and membrane lipids (Aardema et al. 2013, Lolicato et al. 2015). Microarray data from human and mouse comparing cumulus cell transcriptome between in vivo and in vitro maturation highlight differences in some lipid synthesis and metabolism genes (such as Acs/1, Acs/4, Alox5ap, Lpgat1, and Fabp4as) (Ouandaogo et al. 2012, Kind et al. 2013). However, studies on how this impacts lipid composition have not followed-up and is a deficiency in our understanding.

\section{The immune system}

Hypotheses surrounding the similarities between the ovulatory cascade and an immune-regulated event have been proposed over several decades (Espey 1980). While latter work suggested an inflammatory-like state was initiated following the LH-surge (Richards et al. 2002), more recent insights also implicated the involvement an innate, immune-like process (Richards et al. 2008). Research has proposed that an endocrine-immunecytokine network exists within the pre-ovulatory follicle and involving not only inflammatory molecules but also innate immune molecules within the pattern-recognition receptor family.

While several gene expression studies explore the presence and abundance of a number of 'immunecell pathway genes', little functional work has been conducted. Microarray data on cumulus cells during in vivo maturation and expansion of the cumulus oocyte complex identified a number of genes as upregulated over this period (Adam8, Cd28, Pdcd1, Cd34, Cd52, Cd81, Cd97, Emr1, Cd97a, Cd147, Cd166 (Alcam), Cxcr4, Il6, Nurp1, Ptx3, Runx1, Saa3) (HernandezGonzalez et al. 2006), with most never described within the ovary. It is significant that our comparison of COCs derived in vivo and in vitro identified a number of 'immune-cell pathway genes' that were dramatically lower in the in vitro derived COCs (Kind et al. 2013).

Perhaps the most widely explored immune modulator in the COC is Interleukin-6 (IL6). IL6 is significantly upregulated during the ovulatory cascade in vivo (Hernandez-Gonzalez et al. 2006), and known to be regulated during the follicular phase and present in high levels in the periovulatory follicular fluid in humans (Baskind et al. 2014). Liu et al. (2009) explored a functional role for IL6 in the mouse COC during IVM. They reported a short-term induction of $1 / 6$ mRNA in culture that was upregulated by AREG, FSH and PGE2 (4h hCG, Liu et al. 2009), although longer-term regulation in vitro was not explored. The induction was blocked both by indomethacin and RU486, suggesting IL6 is a downstream target of PGE2, and that its expression is modulated by progesterone receptor (Pgr). With a number of these key components dysregulated during IVM (Ptgs1, Ptges, Ptger4, Star, Cyp11a1) (Kind et al. 2013), it is perhaps no surprise that there are alterations in IL6 signalling as a consequence of in vitro maturation. Interestingly, addition of IL6 to IVM was able to promote cumulus expansion in mouse COCs, albeit at concentrations much higher than detectable in follicular fluid; $100-1000 \mathrm{ng} / \mathrm{mL}$ (Liu et al. 2009) vs less than $1-100 \mathrm{pg} / \mathrm{mL}$ detected in human follicular fluid) (Buscher et al. 1999, Altun et al. 2011, Baskind et al. 2014).

A limited amount of data in human suggest that the COC may contain CD4+ T cells, which produce both IL4 and LIF (Piccinni et al. 2001), while a number of chemo-attractants for immune cells including monocytes, dendritic cells and natural killer cells have also been found (Cxcl14, Kind et al. 2013). In addition to this, a number of genes best described as immune cell markers have been found in the COC in vivo, and dysregulated in vitro. Cd83, a marker of fully matured dendritic cells was decreased following in vitro maturation, while $\mathrm{Cd} 14$, a co-receptor for toll-like receptors (TLR), which recognise pathogen-associated molecular patterns (PAMPs), as well as endogenous damage associated molecular patterns (DAMPs) was also decreased in vitro, but present and regulated by $\mathrm{LH}$ (hCG) in vivo (Shimada et al. 2006a). Indeed fragmented hyaluronan and Versican (Kim et al. 2009, Hu et al. 2015) are strong DAMP signals. We propose that the production of inflammatory cytokines and/or immune like behaviour of cumulus cells could represent a final checkpoint prior to ovulation, or at fertilisation, when tissue damage releases DAMP signals that impinge on TLRs and thus are absent when oocytes undergo IVM. As such, IVM followed by intra-cytoplasmic sperm injection (ISCI), where the COC is not exposed to sperm or seminal plasma, may represent a further insult. Future experiments comparing in vivo fertilisation, IVF and ICSI may provide valuable insight into the role of immune factors during oocyte maturation and at fertilisation.

\section{Conclusion}

IVM remains at the fringe of acceptance both clinically and for animal breeding, as it remains less efficient relative to other embryo production strategies. It occupies several niche applications, but is far from widely accepted. Our analysis of cumulus cell transcriptome reveals many different molecular attributes that separate the functionality of cumulus cells from in vivo and in vitro matured COCs, providing a view of the molecular mechanisms behind the wide discrepancy in capacity to generate developmentally competent and mature oocytes. Consistent evidence showing deficient EGF-L signalling, ECM composition and function, metabolism and immune gene expression in IVM as 
well as demonstrating the importance of these pathways in oocyte maturation lead us to conclude that attention given to understanding these molecular mechanisms and to restoring them in IVM will lead to improved IVM efficacy. It is likely an unattainable goal to achieve parity in the transcriptome of these two sources of oocytes, although management of cAMP levels, use of EGF-L peptides, inclusion of specific growth factors, such as cytokines, oocyte secreted factors, and other growth factors (including Versican), providing the correct oxygenation and substrate composition in the medium, will contribute to normalising cumulus cell function and oocyte developmental competence.

\section{Declaration of interest}

The authors declare that there is no conflict of interest that could be perceived as prejudicing the impartiality of this review.

\section{Funding}

This research did not receive any specific grant from any funding agency in the public, commercial or not-forprofit sector.

\section{Acknowledgements}

J G T, H M B and M S-M are supported by the Australian Research Council Centre of Excellence for Nanoscale Biophotonics. D L R, J G T and R B G are recipients of National Health and Medical Research Council Fellowships (IDs 1110562, 1077694, 1023210).

\section{References}

Aardema $\mathrm{H}$, Lolicato $\mathrm{F}$, van de Lest $\mathrm{CH}$, Brouwers JF, Vaandrager AB, van Tol HT, Roelen BA, Vos PL, Helms JB \& Gadella BM 2013 Bovine cumulus cells protect maturing oocytes from increased fatty acid levels by massive intracellular lipid storage. Biology of Reproduction $\mathbf{8 8} 164$. (doi:10.1095/biolreprod.112.106062)

Akison LK, Alvino ER, Dunning KR, Robker RL \& Russell DL 2012 Transient invasive migration in mouse cumulus oocyte complexes induced at ovulation by luteinizing hormone. Biology of Reproduction 86125. (doi:10.1095/biolreprod.111.097345)

Albertini DF, Combelles CM, Benecchi E \& Carabatsos MJ 2001 Cellular basis for paracrine regulation of ovarian follicle development. Reproduction 121 647-653. (doi:10.1530/rep.0.1210647)

Albuz FK, Sasseville M, Lane M, Armstrong DT, Thompson JG \& Gilchrist RB 2010 Simulated physiological oocyte maturation (SPOM): a novel in vitro maturation system that substantially improves embryo yield and pregnancy outcomes. Human Reproduction 25 2999-3011. (doi:10.1093/humrep/deq246)

Altun T, Jindal S, Greenseid K, Shu J \& Pal L 2011 Low follicular fluid IL-6 levels in IVF patients are associated with increased likelihood of clinical pregnancy. Journal of Assisted Reproduction and Genetics 28 245-251. (doi:10.1007/s10815-010-9502-8)

Ashkenazi H, Cao X, Motola S, Popliker M, Conti M \& Tsafriri A 2005 Epidermal growth factor family members: endogenous mediators of the ovulatory response. Endocrinology 146 77-84. (doi:10.1210/ en.2004-0588)
Banwell KM, Lane M, Russell DL, Kind KL \& Thompson JG 2007 Oxygen concentration during mouse oocyte in vitro maturation affects embryo and fetal development. Human Reproduction 22 2768-2775. (doi:10.1093/humrep/dem203)

Baskind NE, Orsi NM \& Sharma V 2014 Follicular-phase ovarian follicular fluid and plasma cytokine profiling of natural cycle in vitro fertilization patients. Fertility and Sterility 102 410-418. (doi:10.1016/j. fertnstert.2014.04.032)

Bermejo-Alvarez P, Lonergan P, Rizos D \& Gutierrez-Adan A 2010 Low oxygen tension during IVM improves bovine oocyte competence and enhances anaerobic glycolysis. Reproductive BioMedicine Online 20 341-349. (doi:10.1016/j.rbmo.2009.12.006)

Bing YZ, Hirao Y, Iga K, Che LM, Takenouchi N, Kuwayama M, Fuchimoto D, Rodriguez-Martinez H \& Nagai T 2002 In vitro maturation and glutathione synthesis of porcine oocytes in the presences of absences of cysteamine under different oxygen tensions: role of cumulus cells. Reproduction Fertility and Development 14 125-131. (doi:10.1071/ RD01127)

Brown HM, Dunning KR, Robker RL, Pritchard M \& Russell DL 2006 Requirement for ADAMTS-1 in extracellular matrix remodeling during ovarian folliculogenesis and lymphangiogenesis. Developmental Biology 300 699-709. (doi:10.1016/j.ydbio.2006.10.012)

Brown HM, Anastasi MR, Frank LA, Kind KL, Richani D, Robker RL, Russell DL, Gilchrist RB \& Thompson JG 2015 Hemoglobin: a gas transport molecule that is hormonally regulated in the ovarian follicle in mice and humans. Biology of Reproduction 92 26. (doi:10.1095/ biolreprod.114.124594)

Buscher U, Chen FC, Kentenich H \& Schmiady H 1999 Cytokines in the follicular fluid of stimulated and non-stimulated human ovaries; is ovulation a suppressed inflammatory reaction? Human Reproduction 14 162-166. (doi:10.1093/humrep/14.1.162)

Caixeta ES, Sutton-McDowall ML, Gilchrist RB, Thompson JG, Price CA, Machado MF, Lima PF \& Buratini J 2013 Bone morphogenetic protein 15 and fibroblast growth factor 10 enhance cumulus expansion, glucose uptake, and expression of genes in the ovulatory cascade during in vitro maturation of bovine cumulus-oocyte complexes. Reproduction 146 27-35. (doi:10.1530/REP-13-0079)

Cakmak H, Franciosi F, Zamah AM, Cedars MI \& Conti M 2016 Dynamic secretion during meiotic reentry integrates the function of the oocyte and cumulus cells. PNAS 113 2424-2429. (doi:10.1073/pnas.1519990113)

Ceko MJ, Hummitzsch K, Hatzirodos N, Bonner WM, Aitken JB, Russell DL, Lane M, Rodgers RJ \& Harris HH 2015 Correction: X-ray fluorescence imaging and other analyses identify selenium and GPX1 as important in female reproductive function. Metallomics 7188 . (doi:10.1039/C4MT90049A)

Chang AS, Dale AN \& Moley KH 2005 Maternal diabetes adversely affects preovulatory oocyte maturation, development, and granulosa cell apoptosis. Endocrinology 146 2445-2453. (doi:10.1210/en.2004-1472)

Chen J, Torcia S, Xie F, Lin CJ, Cakmak H, Franciosi F, Horner K, Onodera C, Song JS, Cedars MI et al. 2013 Somatic cells regulate maternal mRNA translation and developmental competence of mouse oocytes. Nature Cell Biology 15 1415-1423. (doi:10.1038/ncb2873)

Chian RC, Okuda K \& Niwa K 1995 Influence of cumulus cells on in vitro fertilization of bovine oocytes derived from in vitro maturation. Animal Reproduction Science 38 37-48. (doi:10.1016/0378-4320(94)01357-R)

Cillo F, Brevini TA, Antonini S, Paffoni A, Ragni G \& Gandolfi F 2007 Association between human oocyte developmental competence and expression levels of some cumulus genes. Reproduction 134 645-650. (doi:10.1530/REP-07-0182)

Curnow EC, Ryan J, Saunders D \& Hayes ES 2008 Bovine in vitro oocyte maturation as a model for manipulation of the gamma-glutamyl cycle and intraoocyte glutathione. Reproduction Fertility and Development 20 579-588. (doi:10.1071/RD08041)

Curnow EC, Ryan JP, Saunders DM \& Hayes ES 2010 Developmental potential of bovine oocytes following IVM in the presence of glutathione ethyl ester. Reproduction Fertility and Development 22 597-605. (doi:10.1071/RD09228)

Dahlhoff M, Wolf E \& Schneider MR 2014 The ABC of BTC: structural properties and biological roles of betacellulin. Seminars in Cell and Developmental Biology 28 42-48. (doi: (doi:10.1016/j. semcdb.2014.01.002)

de Matos DG \& Furnus CC 2000 The importance of having high glutathione $(\mathrm{GSH})$ level after bovine in vitro maturation on embryo development 
effect of B-mercaptoethanol, cysteine and cystine. Theriogenology 53 761-771. (doi:10.1016/S0093-691X(99)00278-2)

Downs SM, Daniel SA \& Eppig JJ 1988 Induction of maturation in cumulus cell-enclosed mouse oocytes by follicle-stimulating hormone and epidermal growth factor: evidence for a positive stimulus of somatic cell origin. Journal of Experimental Zoology 245 86-96. (doi:10.1002/ jez.1402450113)

Downs SM, Humpherson PG, Martin KL \& Leese HJ 1996 Glucose utilization during gonadotropin-induced meiotic maturation in cumulus cell-enclosed mouse oocytes. Molecular Reproduction and Development 44 121-131. (doi:10.1002/(SICI)1098-2795(199605)44:1<121::AIDMRD14>3.0.CO;2-7)

Du WW, Yang BB, Shatseva TA, Yang BL, Deng Z, Shan SW, Lee DY, Seth A \& Yee AJ 2010 Versican G3 promotes mouse mammary tumor cell growth, migration, and metastasis by influencing EGF receptor signaling. PLOS ONE 5 e13828. (doi:10.1371/journal.pone.0013828)

Dumesic DA, Meldrum DR, Katz-Jaffe MG, Krisher RL \& Schoolcraft WB 2015 Oocyte environment: follicular fluid and cumulus cells are critica for oocyte health. Fertility and Sterility 103 303-316. (doi:10.1016/j. fertnstert.2014.11.015)

Dunning KR \& Robker RL 2012 Promoting lipid utilization with I-carnitine to improve oocyte quality. Animal Reproduction Science 134 69-75. (doi:10.1016/j.anireprosci.2012.08.013)

Dunning KR, Lane M, Brown HM, Yeo C, Robker RL \& Russell DL 2007 Altered composition of the cumulus-oocyte complex matrix during in vitro maturation of oocytes. Human Reproduction 22 2842-2850. (doi:10.1093/humrep/dem277)

Dunning KR, Cashman K, Russell DL, Thompson JG, Norman RJ \& Robker RL 2010 Beta-oxidation is essential for mouse oocyte developmental competence and early embryo development. Biology of Reproduction 83 909-918. (doi:10.1095/biolreprod.110.084145)

Dunning KR, Watson LN, Sharkey DJ, Brown HM, Norman RJ Thompson JG, Robker RL \& Russell DL 2012 Molecular filtration properties of the mouse expanded cumulus matrix: controlled supply of metabolites and extracellular signals to cumulus cells and the oocyte. Biology of Reproduction 87 89. (doi:10.1095/biolreprod.111.096271)

Dunning KR, Anastasi MR, Zhang VJ, Russell DL \& Robker RL 2014 Regulation of fatty acid oxidation in mouse cumulus-oocyte complexes during maturation and modulation by PPAR agonists. PLOS ONE 9 e87327. (doi:10.1371/journal.pone.0087327)

Dunning KR, Watson LN, Zhang VJ, Brown HM, Kaczmarek AK, Robker RL \& Russell DL 2015 Activation of mouse cumulus-oocyte complex maturation in vitro through EGF-like activity of versican. Biology of Reproduction 92 116. (doi:10.1095/biolreprod.114.127274)

Ekart J, McNatty K, Hutton J \& Pitman J 2013 Ranking and selection of MII oocytes in human ICSI cycles using gene expression levels from associated cumulus cells. Human Reproduction 28 2930-2942. (doi:10.1093/humrep/det357)

Eppig JJ 1991 Intercommunication between mammalian oocytes and companion somatic cells. Bioessays 13 569-574. (doi:10.1002/ bies.950131105)

Eppig JJ, Wigglesworth K, Pendola F \& Hirao Y 1997 Murine oocytes suppress expression of luteinizing hormone receptor messenger ribonucleic acid by granulosa cells. Biology of Reproduction $\mathbf{5 6}$ 976-984. (doi:10.1095/biolreprod56.4.976)

Espey LL 1980 Ovulation as an inflammatory reaction - a hypothesis. Biology of Reproduction 22 73-106. (doi:10.1095/biolreprod22.1.73)

Franciosi F, Manandhar S \& Conti M 2016 FSH regulates mRNA translation in mouse oocytes and promotes developmental competence. Endocrinology 157 872-882. (doi:10.1210/en.2015-1727)

Fulop C, Szanto S, Mukhopadhyay D, Bardos T, Kamath RV, Rugg MS, Day AJ, Salustri A, Hascall VC, Glant TT et al. 2003 Impaired cumulus mucification and female sterility in tumor necrosis factor-induced protein-6 deficient mice. Development 130 2253-2261. (doi:10.1242/ dev.00422)

Furnus CC, de Matos DG \& Moses DF 1998 Cumulus expansion during in vitro maturation of bovine oocytes: relationship with intracellular glutathione level and its role on subsequent embryo development. Molecular Reproduction and Development 51 76-83. (doi:10.1002/ (SICI)1098-2795(199809)51:1<76::AID-MRD9>3.0.CO;2-T)

Furnus CC, de Matos DG, Picco S, Garcia PP, Inda AM, Mattioli G \& Errecalde AL 2008 Metabolic requirements associated with GSH synthesis during in vitro maturation of cattle oocytes. Animal Reproduction Science 109 88-99. (doi:10.1016/j.anireprosci.2007.12.003)

Gebhardt KM, Feil DK, Dunning KR, Lane M \& Russell DL 2011 Human cumulus cell gene expression as a biomarker of pregnancy outcome after single embryo transfer. Fertility and Sterility 96 47-52.e42. (doi:10.1016/j.fertnstert.2011.04.033)

Gilchrist RB \& Thompson JG 2007 Oocyte maturation: emerging concepts and technologies to improve developmental potential in vitro. Theriogenology 67 6-15. (doi:10.1016/j.theriogenology.2006.09.027)

Gilchrist RB, Lane M \& Thompson JG 2008 Oocyte-secreted factors: regulators of cumulus cell function and oocyte quality. Human Reproduction Update 14 159-177. (doi:10.1093/humupd/dmm040)

Gilula NB, Epstein ML \& Beers WH 1978 Cell-to-cell communication and ovulation. A study of the cumulus-oocyte complex. Journal of Cell Biology 78 58-75. (doi:10.1083/jcb.78.1.58)

Hammond ER, Stewart B, Peek JC, Shelling AN \& Cree LM 2015 Assessing embryo quality by combining non-invasive markers: early time-lapse parameters reflect gene expression in associated cumulus cells. Human Reproduction 30 1850-1860. (doi:10.1093/humrep/dev121)

Hashimoto S, Minami N, Takakura R, Yamada M, Imai H \& Kashima N 2000a Low oxygen tension during in vitro maturation is beneficial for supporting the subsequent development of bovine cumulus-oocyte complexes. Molecular Reproduction and Development 57 353-360. (doi:10.1002/1098-2795(200012)57:4<353::AID-MRD7>3.0.CO;2-R)

Hashimoto S, Minami N, Yamada M \& Imai H 2000b Excessive concentration of glucose during in vitro maturation impairs the developmental competence of bovine oocytes after in vitro fertilisation: Relevance to intracellular reactive oxygen species and glutathione contents. Molecular Reproduction and Development 56 520-526. (doi:10.1002/1098-2795(200008)56:4<520::AIDMRD10>3.0.CO;2-0)

Hazeleger NL, Hill DJ, Stubbings RB \& Walton JS 1995 Relationship of morphology and follicular fluid environment of bovine oocytes to their developmental potential in vitro. Theriogenelogy 43 509-522. (doi:10.1016/0093-691X(94)00043-T)

Hernandez-Gonzalez I, Gonzalez-Robayna I, Shimada M, Wayne CM, Ochsner SA, White L \& Richards JS 2006 Gene expression profiles of cumulus cell oocyte complexes during ovulation reveal cumulus cells express neuronal and immune-related genes: does this expand their role in the ovulation process? Molecular Endocrinology 20 1300-1321. (doi:10.1210/me.2005-0420)

Hsieh M, Thao K \& Conti M 2011 Genetic dissection of epidermal growth factor receptor signaling during luteinizing hormone-induced oocyte maturation. PLOS ONE 6 e21574. (doi:10.1371/journal.pone.0021574)

Hsieh M, Lee D, Panigone S, Horner K, Chen R, Theologis A, Lee DC, Threadgill DW \& Conti M 2007 Luteinizing hormone-dependent activation of the epidermal growth factor network is essential for ovulation. Molecular and Cellular Biology 27 1914-1924. (doi:10.1128/ MCB.01919-06)

Hu F, a Dzaye OD, Hahn A, Yu Y, Scavetta RJ, Dittmar G, Kaczmarek AK, Dunning KR, Ricciardelli C, Rinnenthal JL et al. 2015 Glioma-derived versican promotes tumor expansion via glioma-associated microglial/ macrophages Toll-like receptor 2 signaling. Neuro-Oncology 17 200-210. (doi:10.1093/neuonc/nou324)

Huang Y, Zhao Y, Yu Y, Li R, Lin S, Zhang C, Liu P \& Qiao J 2015 Altered amphiregulin expression induced by diverse luteinizing hormone receptor reactivity in granulosa cells affects IVF outcomes. Reproductive BioMedicine Online 30 593-601. (doi:10.1016/j.rbmo.2015.03.001)

Hussein TS, Froiland DA, Amato F, Thompson JG \& Gilchrist RB 2005 Oocytes prevent cumulus cell apoptosis by maintaining a morphogenic paracrine gradient of bone morphogenetic proteins. Journal of Cell Science 118 5257-5268. (doi:10.1242/jcs.02644)

Iwamoto M, Onishi A, Fuchimoto D, Somfai T, Takeda K, Tagami T, Hanada H, Noguchi J, Kaneko H, Nagai T et al. 2005 Low oxygen tension during in vitro maturation of porcine follicular oocytes improves parthenogenetic activation and subsequent development to the blastocyst stage. Theriogenology 63 1277-1289. (doi:10.1016/j. theriogenology.2004.05.024)

Jones GM, Cram DS, Song B, Magli MC, Gianaroli L, Lacham-Kaplan O, Findlay JK, Jenkin G \& Trounson AO 2008 Gene expression profiling of human oocytes following in vivo or in vitro maturation. Human Reproduction 23 1138-1144. (doi:10.1093/humrep/den085) 
Kawashima I, Liu Z, Mullany LK, Mihara T, Richards JS \& Shimada M 2012 EGF-like factors induce expansion of the cumulus cell-oocyte complexes by activating calpain-mediated cell movement. Endocrinology 153 3949-3959. (doi:10.1210/en.2012-1059)

Kawashima I, Umehara T, Noma N, Kawai T, Shitanaka M, Richards JS \& Shimada M 2014 Targeted disruption of Nrg1 in granulosa cells alters the temporal progression of oocyte maturation. Molecular Endocrinology $\mathbf{2 8}$ 706-721. (doi:10.1210/me.2013-1316)

Kidder GM \& Vanderhyden BC 2010 Bidirectional communication between oocytes and follicle cells: ensuring oocyte developmental competence. Canadian Journal of Physiology and Pharmacology $\mathbf{8 8}$ 399-413. (doi:10.1139/Y10-009)

Kim S, Takahashi H, Lin WW, Descargues P, Grivennikov S, Kim Y, Luo JL \& Karin M 2009 Carcinoma-produced factors activate myeloid cells through TLR2 to stimulate metastasis. Nature 457 102-106. (doi:10.1038/nature07623)

Kind KL, Banwell KM, Gebhardt KM, Macpherson A, Gauld A, Russell DL \& Thompson JG 2013 Microarray analysis of mRNA from cumulus cells following in vivo or in vitro maturation of mouse cumulus-oocyte complexes. Reproduction Fertility and Development 25 426-438. (doi:10.1071/RD11305)

Krisher R 2013 In vivo and in vitro environmental effects on mammalian oocyte quality. Annual Review of Animal Bioscience 1 393-417. (doi:10.1146/annurev-animal-031412-103647)

Lam X, Gieseke C, Knoll M \& Talbot P 2000 Assay and importance of adhesive interaction between hamster (Mesocricetus auratus) oocyte-cumulus complexes and the oviductal epithelium. Biology of Reproduction 62 579-588. (doi:10.1095/biolreprod62.3.579)

Leroy JL, Van Soom A, Opsomer G \& Bols PE 2008 The consequences of metabolic changes in high-yielding dairy cows on oocyte and embryo quality. Animal 2 1120-1127. (doi:10.1017/ s1751731108002383)

Liu Z, de Matos DG, Fan HY, Shimada M, Palmer S \& Richards JS 2009 Interleukin-6: an autocrine regulator of the mouse cumulus celloocyte complex expansion process. Endocrinology 150 3360-3368. (doi:10.1210/en.2008-1532)

Lolicato F, Brouwers JF, de Lest $\mathbf{C H}$, Wubbolts $\mathbf{R}$, Aardema $\mathbf{H}$, Priore P, Roelen BA, Helms JB \& Gadella BM 2015 The cumulus cell layer protects the bovine maturing oocyte against fatty acidinduced lipotoxicity. Biology of Reproduction 92 16. (doi:10.1095/ biolreprod.114.120634)

Luciano AM, Lodde V, Beretta MS, Colleoni S, Lauria A \& Modina S 2005 Developmental capability of denuded bovine oocyte in a coculture system with intact cumulus-oocyte complexes: role of cumulus cells, cyclic adenosine 3',5'-monophosphate and glutathione. Molecular Reproduction and Development 71 389-397. (doi:10.1002/ mrd.20304)

Mahtouk K, Cremer FW, Reme T, Jourdan M, Baudard M, Moreaux J, Requirand G, Fiol G, De Vos J, Moos M et al. 2006 Heparan sulphate proteoglycans are essential for the myeloma cell growth activity of EGF-family ligands in multiple myeloma. Oncogene 25 7180-7191. (doi:10.1038/sj.onc.1209699)

Matzuk MM, Burns KH, Viveiros MM \& Eppig JJ 2002 Intercellular communication in the mammalian ovary: oocytes carry the conversation. Science 296 2178-2180. (doi:10.1126/science.1071965)

McKenzie LJ, Pangas SA, Carson SA, Kovanci E, Cisneros P, Buster JE, Amato P \& Matzuk MM 2004 Human cumulus granulosa cell gene expression: a predictor of fertilization and embryo selection in women undergoing IVF. Human Reproduction 19 2869-2874. (doi:10.1093/ humrep/deh535)

Mester B, Ritter LJ, Pitman JL, Bibby AH, Gilchrist RB, McNatty KP, Juengel JL \& Mclntosh CJ 2015 Oocyte expression, secretion and somatic cell interaction of mouse bone morphogenetic protein 15 during the peri-ovulatory period. Reproduction, Fertility and Development $\mathbf{2 7}$ 801-811. (doi:10.1071/RD13336)

Mittaz L, Russell DL, Wilson T, Brasted M, Tkalcevic J, Salamonsen LA, Hertzog PJ \& Pritchard MA 2004 Adamts-1 is essential for the development and function of the urogenital system. Biology of Reproduction 70 1096-1105. (doi:10.1095/biolreprod.103.023911)

Noma N, Kawashima I, Fan HY, Fujita Y, Kawai T, Tomoda Y, Mihara T, Richards JS \& Shimada M 2011 LH-induced neuregulin 1 (NRG1) type III transcripts control granulosa cell differentiation and oocyte maturation. Molecular Endocrinology 25 104-116. (doi:10.1210/ me.2010-0225)

Ochsner SA, Russell DL, Day AJ, Breyer RM \& Richards JS 2003 Decreased expression of tumor necrosis factor-alpha-stimulated gene 6 in cumulus cells of the cyclooxygenase-2 and EP2 null mice. Endocrinology 144 1008-1019. (doi:10.1210/en.2002-220435)

Odor DL \& Blandau RJ 1973 EGG transport over the fimbrial surface of the rabbit oviduct under experimental conditions. Fertility and Sterility $\mathbf{2 4}$ 292-300. (doi:10.1016/S0015-0282(16)39614-5)

Ouandaogo ZG, Frydman N, Hesters L, Assou S, Haouzi D, Dechaud H, Frydman R \& Hamamah S 2012 Differences in transcriptomic profiles of human cumulus cells isolated from oocytes at GV, MI and MII stages after in vivo and in vitro oocyte maturation. Human Reproduction 27 2438-2447. (doi:10.1093/humrep/des172)

Park JY, Su YQ, Ariga M, Law E, Jin SL \& Conti M 2004 EGF-like growth factors as mediators of LH action in the ovulatory follicle. Science $\mathbf{3 0 3}$ 682-684. (doi:10.1126/science.1092463)

Peluffo MC, Ting AY, Zamah AM, Conti M, Stouffer RL, Zelinski MB \& Hennebold JD 2012 Amphiregulin promotes the maturation of oocytes isolated from the small antral follicles of the rhesus macaque. Human Reproduction 27 2430-2437. (doi:10.1093/humrep/des158)

Piccinni MP, Scaletti C, Mavilia C, Lazzeri E, Romagnani P, Natali I, Pellegrini S, Livi C, Romagnani S \& Maggi E 2001 Production of IL-4 and leukemia inhibitory factor by $\mathrm{T}$ cells of the cumulus oophorus: a favorable microenvironment for pre-implantation embryo development. European Journal of Immunology 31 2431-2437. (doi:10.1002/15214141(200108)31:8<2431::AID-IMMU2431>3.0.CO;2-U)

Preis KA, Seidel GE Jr \& Gardner DK 2007 Reduced oxygen concentration improves the developmental competence of mouse oocytes following in vitro maturation. Molecular Reproduction and Development $\mathbf{7 4}$ 893-903. (doi:10.1002/mrd.20655)

Purcell SH \& Moley KH 2011 The impact of obesity on egg quality. Journal of Assisted Reproduction and Genetics 28 517-524. (doi:10.1007/ s10815-011-9592-y)

Quinn P \& Harlow GM 1978 The effect of oxygen on the development of preimplantation mouse embryos in vitro. Journal of Experimental Zoology 206 73-80. (doi:10.1002/jez.1402060108)

Richani D, Ritter LJ, Thompson JG \& Gilchrist RB 2013 Mode of oocyte maturation affects EGF-like peptide function and oocyte competence. Molecular Human Reproduction 19 500-509. (doi:10.1093/molehr/gat028)

Richani D, Sutton-McDowall ML, Frank LA, Gilchrist RB \& Thompson JG 2014a Effect of epidermal growth factor-like peptides on the metabolism of in vitro-matured mouse oocytes and cumulus cells. Biology of Reproduction 90 49. (doi:10.1095/biolreprod.113.115311)

Richani D, Wang X, Zeng HT, Smitz J, Thompson JG \& Gilchrist RB $2014 b$ Pre-maturation with CAMP modulators in conjunction with EGF-like peptides during in vitro maturation enhances mouse oocyte developmental competence. Molecular Reproduction and Development 81 422-435. (doi:10.1002/mrd.22307)

Richards JS, Russell DL, Ochsner S \& Espey LL 2002 Ovulation: new dimensions and new regulators of the inflammatory-like response. Annual Review of Physiology 64 69-92. (doi:10.1146/annurev. physiol.64.081501.131029)

Richards JS, Liu Z \& Shimada M 2008 Immune-like mechanisms in ovulation. Trends in Endocrinology and Metabolism 19 191-196. (doi:10.1016/j.tem.2008.03.001)

Robker RL 2008 Evidence that obesity alters the quality of oocytes and embryos. Pathophysiology 15 115-121. (doi:10.1016/j. pathophys.2008.04.004)

Roepstorff K, Grandal MV, Henriksen L, Knudsen SL, Lerdrup M, Grovdal L, Willumsen BM \& van Deurs B 2009 Differential effects of EGFR ligands on endocytic sorting of the receptor. Traffic 10 1115-1127. (doi:10.1111/j.1600-0854.2009.00943.x)

Russell DL \& Salustri A 2006 Extracellular matrix of the cumulusoocyte complex. Seminars in Reproductive Medicine 24 217-227. (doi:10.1055/s-2006-948551)

Russell DL \& Robker RL 2007 Molecular mechanisms of ovulation: coordination through the cumulus complex. Human Reproduction Update 13 289-312. (doi:10.1093/humupd/dml062)

Russell DL, Doyle KM, Ochsner SA, Sandy JD \& Richards JS 2003a Processing and localization of ADAMTS-1 and proteolytic cleavage 
of versican during cumulus matrix expansion and ovulation. Journal of Biological Chemistry 278 42330-42339. (doi:10.1074/jbc. M300519200)

Russell DL, Ochsner SA, Hsieh M, Mulders S \& Richards JS 2003b Hormone-regulated expression and localization of versican in the rodent ovary. Endocrinology 144 1020-1031. (doi:10.1210/en.2002220434)

Salavati M, Ghafari F, Zhang T \& Fouladi-Nashta AA 2012 Effects of oxygen concentration on in vitro maturation of canine oocytes in a chemically defined serum-free medium. Reproduction 144 547-556. (doi:10.1530/ REP-12-0176)

Salhab M, Dhorne-Pollet S, Auclair S, Guyader-Joly C, Brisard D, Dalbies-Tran R, Dupont J, Ponsart C, Mermillod P \& Uzbekova S 2013 In vitro maturation of oocytes alters gene expression and signaling pathways in bovine cumulus cells. Molecular Reproduction and Development 80 166-182. (doi:10.1002/mrd.22148)

Salustri A, Garlanda C, Hirsch E, De Acetis M, Maccagno A, Bottazzi B, Doni A, Bastone A, Mantovani G, Beck Peccoz P et al. 2004 PTX3 plays a key role in the organization of the cumulus oophorus extracellular matrix and in in vivo fertilization. Development 131 1577-1586. (doi:10.1242/dev.01056)

Shimada M, Hernandez-Gonzalez I, Gonzalez-Robanya I \& Richards JS 2006 a Induced expression of pattern recognition receptors in cumulus oocyte complexes: novel evidence for innate immune-like functions during ovulation. Molecular Endocrinology $203228-3239$. (doi:10.1210/ me.2006-0194)

Shimada M, Hernandez-Gonzalez I, Gonzalez-Robayna I \& Richards JS $2006 b$ Paracrine and autocrine regulation of epidermal growth factor-like factors in cumulus oocyte complexes and granulosa cells: key roles for prostaglandin synthase 2 and progesterone receptor. Molecular Endocrinology 20 1352-1365. (doi:10.1210/ me.2005-0504)

Sugimura S, Ritter LJ, Sutton-McDowall ML, Mottershead DG, Thompson JG \& Gilchrist RB 2014 Amphiregulin co-operates with bone morphogenetic protein 15 to increase bovine oocyte developmental competence: effects on gap junction-mediated metabolite supply. Molecular Human Reproduction 20 499-513. (doi:10.1093/molehr/ gau013)

Sugimura S, Ritter LJ, Rose RD, Thompson JG, Smitz J, Mottershead DG \& Gilchrist RB 2015 Promotion of EGF receptor signaling improves the quality of low developmental competence oocytes. Developmental Biology 403 139-149. (doi:10.1016/j.ydbio.2015.05.008)

Sugiura K \& Eppig JJ 2005 Society for Reproductive Biology Founders Lecture 2005. Control of metabolic cooperativity between oocytes and their companion granulosa cells by mouse oocytes. Reproduction, Fertility and Development 17 667-674. (doi:10.1071/RD05071)

Sugiura K, Pendola FL \& Eppig JJ 2005 Oocyte control of metabolic cooperativity between oocytes and companion granulosa cells: energy metabolism. Developmental Biology 279 20-30. (doi:10.1016/j. ydbio.2004.11.027)

Sugiura K, Su YQ, Diaz FJ, Pangas SA, Sharma S, Wigglesworth K, O'Brien MJ, Matzuk MM, Shimasaki S \& Eppig JJ 2007 Oocyte-derived BMP15 and FGFs cooperate to promote glycolysis in cumulus cells. Development 134 2593-2603. (doi:10.1242/dev.006882)

Sutovsky P \& Schatten G 1997 Depletion of glutathione during bovine oocyte maturation reversibility blocks the decondensation of the male pronucleus and pronuclear apposition during fertilization. Biology of Reproduction 56 1503-1512. (doi:10.1095/ biolreprod56.6.1503)

Sutton-McDowall ML, Gilchrist RB \& Thompson JG 2004 Cumulus expansion and glucose utilisation by bovine cumulus-oocyte complexes during in vitro maturation: the influence of glucosamine and folliclestimulating hormone. Reproduction 128 313-319. (doi:10.1530/ rep.1.00225)

Sutton-McDowall M, Gilchrist R \& Thompson J 2010 The pivotal role of glucose metabolism in determining oocyte developmental competence. Reproduction 139 685-695. (doi:10.1530/REP-09-0345)

Tatone C, Carbone MC, Campanella G, Festuccia C, Artini PG, Talesa V, Focarelli R \& Amicarelli F 2010 Female reproductive dysfunction during ageing: role of methylglyoxal in the formation of advanced glycation endproducts in ovaries of reproductively-aged mice. Journal of Biological Regulators and Homeostatic Agents 24 63-72.
Tatone C, Heizenrieder T, Di Emidio G, Treffon P, Amicarelli F, Seidel T \& Eichenlaub-Ritter U 2011 Evidence that carbonyl stress by methylglyoxal exposure induces DNA damage and spindle aberrations, affects mitochondrial integrity in mammalian oocytes and contributes to oocyte ageing. Human Reproduction 26 1843-1859. (doi:10.1093/ humrep/der140)

Tesfaye D, Ghanem N, Carter F, Fair T, Sirard MA, Hoelker M, Schellander K \& Lonergan P 2009 Gene expression profile of cumulus cells derived from cumulus-oocyte complexes matured either in vivo or in vitro. Reproduction Fertility and Development 21 451-461. (doi:10.1071/ RD08190)

Thompson JG, Lane M \& Gilchrist RB 2007 Metabolism of the bovine cumulus-oocyte complex and influence on subsequent developmental competence. Society for Reproduction and Fertility Supplement 64 179-190. (doi:10.5661/rdr-vi-179)

Thompson JG, Gilchrist RB \& Sutton-McDowall ML 2014 The metabolism of the ruminant cumulus-oocyte complex revisited. In Reproduction in Domestic Ruminants VIII. Eds A Miyamoto, JL Juengel, C Price, LP Reynolds, MF Smith \& R Webb. Leicestershire, UK: Context Products.

Thompson JG, Brown HM, Kind KL \& Russell DL 2015 The ovarian antral follicle: living on the edge of hypoxia or not? Biology of Reproduction 92 153. (doi:10.1095/biolreprod.115.128660)

Van Hoeck V, Sturmey RG, Bermejo-Alvarez P, Rizos D, Gutierrez-Adan A, Leese HJ, Bols PE \& Leroy JL 2011 Elevated nonesterified fatty acid concentrations during bovine oocyte maturation compromise early embryo physiology. PLOS ONE 6 e23183. (doi:10.1371/journal.pone.0023183)

Varani S, Elvin JA, Yan C, DeMayo J, DeMayo FJ, Horton HF, Byrne MC \& Matzuk MM 2002 Knockout of pentraxin 3, a downstream target of growth differentiation factor-9, causes female subfertility. Molecular Endocrinology 16 1154-1167. (doi:10.1210/mend.16.6.0859)

Walls M, Junk S, Ryan JP \& Hart R 2012 IVF versus ICSI for the fertilization of in-vitro matured human oocytes. Reproductive BioMedicine Online 25 603-607. (doi:10.1016/j.rbmo.2012.08.001)

Walls ML, Hunter T, Ryan JP, Keelan JA, Nathan E \& Hart RJ 2015 In vitro maturation as an alternative to standard in vitro fertilization for patients diagnosed with polycystic ovaries: a comparative analysis of fresh, frozen and cumulative cycle outcomes. Human Reproduction 30 88-96. (doi:10.1093/humrep/deu248)

Wathlet S, Adriaenssens T, Segers I, Verheyen G, Van de Velde H, Coucke W, Ron El R, Devroey P \& Smitz J 2011 Cumulus cell gene expression predicts better cleavage-stage embryo or blastocyst development and pregnancy for ICSI patients. Human Reproduction 26 1035-1051. (doi:10.1093/humrep/der036)

Watson LN, Mottershead DG, Dunning KR, Robker RL, Gilchrist RB \& Russell DL 2012 Heparan sulfate proteoglycans regulate responses to oocyte paracrine signals in ovarian follicle morphogenesis. Endocrinology 153 4544-4555. (doi:10.1210/en.2012-1181)

Wells D \& Patrizio P 2008 Gene expression profiling of human oocytes at different maturational stages and after in vitro maturation. American Journal of Obstetrics and Gynecology 198 455.e451-459; discussion 455.e459-411. (doi:10.1016/j.ajog.2007.12.030)

Wilson KJ, Mill C, Lambert S, Buchman J, Wilson TR, Hernandez-Gordillo V, Gallo RM, Ades LM, Settleman J \& Riese DJ 2nd 2012 EGFR ligands exhibit functional differences in models of paracrine and autocrine signaling. Growth Factors 30 107-116. (doi:10.3109/08977194.2011.649918)

Xie HL, Wang YB, Jiao GZ, Kong DL, Li Q, Li H, Zheng LL \& Tan JH 2016 Effects of glucose metabolism during in vitro maturation on cytoplasmic maturation of mouse oocytes. Scientific Reports 6 20764. (doi:10.1038/ srep20764)

Xu X, Chen D, Zhang Z, Wei Z \& Cao Y 2015 Molecular signature in human cumulus cells related to embryonic developmental potential. Reproductive Sciences 22 173-180. (doi:10.1177/1933719114536471)

Younis Al \& Brackett BG 1991 Importance of cumulus cells and insemination intervals for development of bovine oocytes into morulae and blastocysts in vitro. Theriogenology 36 11-21. (doi:10.1016/0093691X(91)90429-H)

Yung Y, Maman E, Konopnicki S, Cohen B, Brengauz M, Lojkin I, Dal Canto M, Fadini R, Dor J \& Hourvitz A 2010 ADAMTS-1: a new human ovulatory gene and a cumulus marker for fertilization capacity. 
Molecular and Cellular Endocrinology 328 104-108. (doi:10.1016/j. mce.2010.07.019)

Zamah AM, Hsieh M, Chen J, Vigne JL, Rosen MP, Cedars MI \& Conti M 2010 Human oocyte maturation is dependent on LH-stimulated accumulation of the epidermal growth factor-like growth factor, amphiregulin. Human Reproduction 25 2569-2578. (doi:10.1093/ humrep/deq212)

Zeng HT, Richani D, Sutton-McDowall ML, Ren Z, Smitz JE, Stokes Y, Gilchrist RB \& Thompson JG 2014 Prematuration with cyclic adenosine monophosphate modulators alters cumulus cell and oocyte metabolism and enhances developmental competence of in vitromatured mouse oocytes. Biology of Reproduction 91 47. (doi:10.1095/ biolreprod.114.118471
Zhang L, Jiang S, Wozniak PJ, Yang X \& Godke RA 1995 Cumulus cell function during bovine oocyte maturation, fertilization, and embryo development in vitro. Molecular Reproduction and Development $\mathbf{4 0}$ 338-344. (doi:10.1002/mrd.1080400310)

Received 4 August 2016

First decision 12 October 2016

Revised manuscript received 8 November 2016

Accepted 21 November 2016 